\title{
Effects of Th17/Treg cell imbalance on HIV replication in patients with AIDS complicated with tuberculosis
}

\author{
YANSHUANG LI and WEIJIA SUN \\ Xiangya Hospital, Central South University, Changsha, Hunan 410008, P.R. China
}

Received April 10, 2017; Accepted September 4, 2017

DOI: $10.3892 /$ etm.2018.5768

\begin{abstract}
The purpose of this study was to determine the effect of Th17/Treg cell imbalance on HIV replication in patients with AIDS complicated with tuberculosis (TB). We selected 32 patients with AIDS combined with TB infection in our hospital and 30 healthy individual as controls. The Th17/Treg ratio in peripheral blood lymphocytes was detected by flow cytometry. Compared with healthy subjects, Th17 cells first declined in HIV patients with TB, but gradually increased over the course of the disease. Treg showed an increasing trend in HIV patients with TB. The Th17/Treg ratio was significantly altered as the condition gradually deteriorated. ELISA showed that interleukin (IL)-17, IL-6 and IL-10 in patients with HIV complicated with TB were significantly lower than in healthy subjects. The imbalance of Th17/Treg cells can promote HIV virus replication in AIDS patients with TB infection, which can aggravate the condition.
\end{abstract}

\section{Introduction}

The human immunodeficiency virus (HIV) is the main cause of the acquired immune deficiency syndrome (AIDS) (1). HIV is an RNA retrovirus that infects immune cells and uses the host cell transcriptional and translational machineries to proliferate and, at the same time, undermine the health of the human host. By 2015 there were nearly 40 million AIDS patients worldwide (2), with an increasing trend and a shift towards the younger population. By the end of 2015 , $\sim 1$ million people had AIDS in China, with the population below 45 years accounting for $86.4 \%$ of all patients. Therefore, strengthening the diagnosis and treatment of AIDS is critical to control this global epidemic. Clinical research shows that Mycobacterium tuberculosis (M. tuberculosis) is the main pathogen causing AIDS mortality (3). M. tuberculosis can

Correspondence to: Dr Weijia Sun, Xiangya Hospital, Central South University, 87 Xiangya Road, Changsha, Hunan 410008, P.R. China

E-mail: hzo233494@163.com

Key words: Th17/Treg, cell immune imbalance, HIV complications, tuberculosis proliferate in AIDS patients and destruct the respiratory system and other organs. Studies have shown that the main clinical features of AIDS are $\mathrm{CD}^{+} \mathrm{T}$ cell reduction, excessive immune activation, and rapid increase in HIV (4). As the main target of HIV/AIDS, CD4 ${ }^{+} \mathrm{T}$ cells play an important role in the occurrence and development of AIDS. In recent years, research has shown that differentiation and maturation of T helper 17 (Th17) and T regulatory (Treg) cells from CD4 ${ }^{+}$ $\mathrm{T}$ cells play key roles in resistance to amplification and invasion of the HIV virus.

Interleukin-17 (IL-17) promotes the expression of cytokines and plays an important role in the inflammatory immune response. Th17 cells are thought to have a significant inhibitory effect on the replication and amplification of the HIV. Research shows that Th17 in the late stage of infection and the early stage of inflammation can promote the expression of immune factors, link innate and adaptive immunity, and improve overall immunity (5). The main role of Treg is to inhibit the effect of $\mathrm{T}$ lymphocytes to prevent excessive autoimmune symptoms, thereby reducing the body resistance to external pathogens. Under normal circumstances, the Th17/Treg ratio is relatively stable, but inflammation and other immune conditions disturb this balance (6). For example, during inflammation, TGF- $\beta$ can promote Treg cell production and promote the differentiation of Th17 and other cells. In the later stages of the inflammatory reaction, TGF- $\beta$ can inhibit the immune response by inhibiting the proliferation of Treg cells, so the Th17/Treg balance is critical to maintain the normal immune function. There are few reports about the effect of Th17/Treg cell immune imbalance on HIV replication in patients with AIDS complicated with tuberculosis (TB) (7). Here, we studied for the first time the Th17/Treg cell immune imbalance effect on virus replication in AIDS patients with TB. Overall, we want to provide the theoretical and experimental basis to diagnose and treat patients with AIDS complicated with TB.

\section{Materials and methods}

Patient information. We recruited 32 patients treated for AIDS combined with TB infection in Xiangya Hospital from January 2011 to March 2015. Among them, 18 were male and 14 were female. The average age was $35.3 \pm 12.5$ years. Thirty healthy individuals were also recruited as controls, including 18 males and 14 females, with an average age of $32.7 \pm 13.2$ years. The studywas approved by the Ethics 
Committee of Xiangya Hospital and informed consents were signed by the patients and/or guardians.

Inclusion criteria: i) HIV patients with TB; and ii) ages between 20 and 50 years. Exclusion criteria: i) Other inflammatory diseases; ii) suffering from other immune system diseases; and iii) ages below 20 years and over 50 years.

Reagents and instruments. Main reagents: Fetal bovine serum (FBS) and L-glutamic acid (both from Hyclone, Logan, UT, USA), PBS buffer solution (Alfa, Suzhou, China), monoclonal first antibody of IL-17, IL-6 and IL-10, and HRP-labeled polyclonal second antibody (both from Thermo Fisher Scientific, Inc., Waltham, MA, USA).

Main instruments: Flow cytometry, biological safety cabinet and nitrogen canister (all from Thermo Fisher Scientific, Inc.), protein electrophoresis apparatus (Beijing 61 Instrument Factory, Beijing, China), low-temperature high-speed centrifuge (Hitachi, Tokyo, Japan), and cell counter (Thermo Fisher Scientific, Inc.).

Sample collection. We collected $5 \mathrm{ml}$ of elbow vein blood through the EDTA anticoagulation (Applied Biosystems, Foster City, CA, USA) vacuum collected blood vessels, and carried on the examination in $12 \mathrm{~h}$.

Cell count. We used flow cytometry to carry out technical statistics on different cells. The method was first to take the $15 \mu 1$ CD4-FTTC monoclonal antibody (Acris Antibodies, Inc., San Diego, CA, USA) into the sample tube of the flow cytometry, and then add $50 \mu 1$ of each blood sample, gently mix evenly, and preservation avoiding light and store it at room temperature for $10 \mathrm{~min}$. Then, the percentage of $\mathrm{CD}^{+} \mathrm{T}$ cells and the total cells were detected by flow cytometry (8).

Enzyme-linked immune response. Total protein samples were obtained and the expression of IL-17, IL-6 and IL-10 were determined by ELISA, and the specific operation was performed in accordance with the ELISA kit (Qiagen $\mathrm{GmbH}$, Hilden, Germany) instructions. The standard curve was made according to the ELISA standard curve step and the protein samples were diluted in elution buffer with a ratio of 1:100. After diluting the samples with sterilized PBS ( $\mathrm{pH}$ 7.2) with a ratio of 1:200, $100 \mu \mathrm{l}$ were added to a 96-well plate, and then $50 \mu \mathrm{l}$ were added to each well. After incubation at room temperature for $2 \mathrm{~h}$, the TMB substrate was added, with the determination of absorbance at $495 \mathrm{~nm}$. Then, the IL-17, IL- 6 and IL-10 concentration in each sample were calculated according to the standard curve (9).

Treg cell expression level detection. Two flow type tubes were used as the test and control tubes. The liquid transfer gun was used to add $100 \mu \mathrm{l}$ cells at $10^{6} / \mathrm{ml}$ and $10 \mu \mathrm{l}$ CD4-PE/CD25-APC (Becton-Dickinson, San Jose, CA, USA), placed at $4^{\circ} \mathrm{C}$ for $30 \mathrm{~min}, 1 \mathrm{ml}$ fixative solution (BD Biosciences, Franklin Lakes, NJ, USA) was added and mixed well, incubated at $4^{\circ} \mathrm{C}$ avoiding light for $30 \mathrm{~min}$, and centrifuge washing with permeabilization buffer. Then, $1 \mu 1$ 1 rat serum was added with $4^{\circ} \mathrm{C}$ incubation for $15 \mathrm{~min}, 2.5 \mu \mathrm{l}$ PE anti-mouse/rat Foxp3 antibody (BD Biosciences) and $2.5 \mu \mathrm{PE}$ rat $\lg \mathrm{G} 2 \mathrm{a}$ homotype were added with $4^{\circ} \mathrm{C}$ incubation
Table I. Baseline expression of Th17 cells in peripheral blood lymphocytes.

\begin{tabular}{lccc}
\hline Groups & $\begin{array}{c}\text { No. of } \\
\text { cases }\end{array}$ & $\begin{array}{c}\mathrm{CD}^{+} \\
(\text {cells } / \mu \mathrm{l})\end{array}$ & $\begin{array}{c}\text { Th17 cells } \\
(\%)\end{array}$ \\
\hline $\begin{array}{l}\text { Healthy } \\
\text { population }\end{array}$ & 30 & $912 \pm 254$ & $4.24 \pm 0.36$ \\
$\begin{array}{l}\text { HIV complicated with } \\
\text { tuberculosis infection }\end{array}$ & 32 & $145 \pm 38$ & $1.21 \pm 0.13$ \\
\hline
\end{tabular}

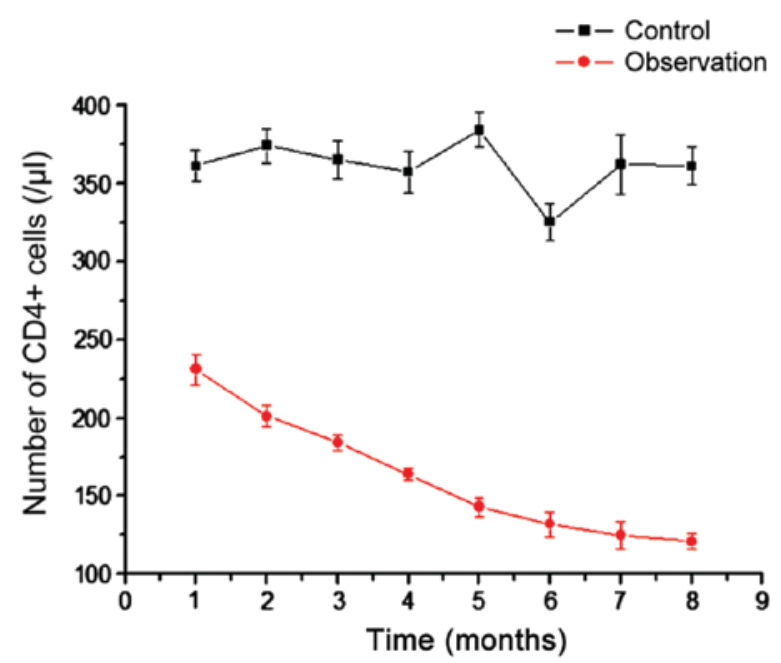

Figure $1 . \mathrm{CD}^{+} \mathrm{T}$ cell count in peripheral blood lymphocytes in the observation and the control groups.

in the dark for $30 \mathrm{~min}$. After three washes, $500 \mu \mathrm{l}$ of Flow Cytometry Staining Buffer (BD Biosciences) was added. Finally, flow cytometry was used to analyze the expression level of Treg on $\mathrm{CD}^{+} \mathrm{T}$ lymphocytes (10).

Th7 cell expression detection. Peripheral venous blood (10 ml) was collected, peripheral mononuclear cells (PBMC) were separated by Ficoll density gradient centrifugation, PBMC density was adjusted to $2 \times 10^{6} / \mathrm{ml}$, and resuspended in RPMI-1640 culture medium (Invitrogen Life Technologies, Carlsbad, CA, USA). PBMC suspension $2 \times 10^{6} / \mathrm{ml}$ was added into the 24-well culture plates, $1 \mathrm{ml} /$ well, $20 \mathrm{ng} / \mathrm{ml}$ phorbol myristate acetate (PMA) and $1 \mu \mathrm{g} / \mathrm{ml}$ ionomycin (both from Sigma-Aldrich; Merck KGaA, Darmstadt, Germany), were cultivated for $2 \mathrm{~h}$ in the culture box $\left(37^{\circ} \mathrm{C}, 5 \% \mathrm{CO}_{2}\right)$, then the monensin $2 \mathrm{nmol} / \mathrm{ml}$ (Sigma-Aldrich; Merck KGaA), was added and cultured for $2 \mathrm{~h}$. The cells were collected, washed 3 times in PBS and divided into control and test tubes. Each tube received $10 \mu \mathrm{l}$ CD4-FITC (Becton-Dickinson), then incubated for $15 \mathrm{~min}$ at room temperature, adding $100 \mu \mathrm{l}$ fixative with mixing at room temperature for $15 \mathrm{~min}$, after PBS washing 3 times, $100 \mu \mathrm{l}$ of film developing agent was added, gently mixed evenly, and placed at room temperature in the dark for $5 \mathrm{~min}$. In the experimental tube, we added $5 \mu 1$ of anti-human IL-17 mAb (BD Biosciences). Into the control tubes, $5 \mu 1$ of control antibody IgG-PE was added. The tubes were mixed at room temperature for $30 \mathrm{~min}$ in the dark. After 
Table II. Baseline expression of Treg cells in peripheral blood lymphocytes.

\begin{tabular}{lccc}
\hline Groups & $\begin{array}{c}\text { No. of } \\
\text { cases }\end{array}$ & $\begin{array}{c}\mathrm{CD}^{+} \\
(\mathrm{cells} / \mu \mathrm{l})\end{array}$ & $\begin{array}{c}\text { Treg cells } \\
(\%)\end{array}$ \\
\hline $\begin{array}{l}\text { Healthy } \\
\text { population }\end{array}$ & 30 & $912 \pm 254$ & $4.24 \pm 0.36$ \\
$\begin{array}{l}\text { HIV complicated with } \\
\text { tuberculosis infection }\end{array}$ & 32 & $1.832 \pm 316$ & $9.14 \pm 1.31$ \\
\hline
\end{tabular}

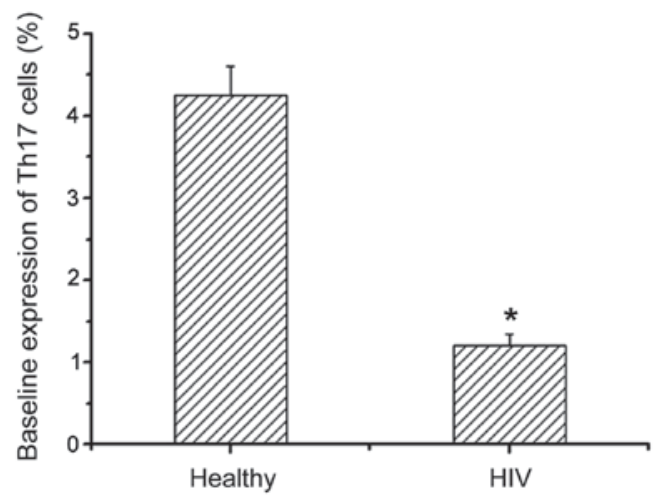

Figure 2. Baseline expressions of Th17 cells in peripheral blood lymphocytes in the observation and the control groups. "Statistically significant difference between groups at $\mathrm{P}<0.05$.

3 PBS washes, the cells were detected by flow cytometry with $500 \mu 1$ PBS suspension cells, and the expression level of Th17 cells was analyzed by $\mathrm{CD} 4^{+} \mathrm{T}$ lymphocytes (10).

Viral load measurement. Viral loads in different blood samples were measured by COBAS kit (Roche Diagnostics, Indianapolis, IN, USA). The kit could be used for quantitative determination of viral load (fluorescent quantitative PCR), and the process was carried out following the instructions of the manufacturer.

Statistical analysis. The experimental data were processed with SPSS 20.0 (SPSS, Inc., Chicago, IL, USA) statistical software. The experimental data are expressed as mean \pm SD Single factor analysis method was used to analyze the data between different groups. $\mathrm{P}<0.05$ was considered to indicate a statistically significant difference.

\section{Results}

$C D 4^{+} T$ cell count in peripheral blood lymphocytes. We analyzed the number of $\mathrm{CD}^{+} \mathrm{T}$ cells in the control and observation groups (Fig. 1). Compared with $\mathrm{CD} 4^{+} \mathrm{T}$ cells in the blood of healthy people, the $\mathrm{CD}^{+} \mathrm{T}$ cells in the observation group were significantly reduced, and the difference was more significant with time (Fig. 1). This shows that AIDS with $\mathrm{TB}$ infection can reduce the number of $\mathrm{CD} 4^{+} \mathrm{T}$ cells. As the main immune cells infected by HIV, the gradual decrease in the number of $\mathrm{CD} 4^{+} \mathrm{T}$ cells can explain the increasing number of viral particles.

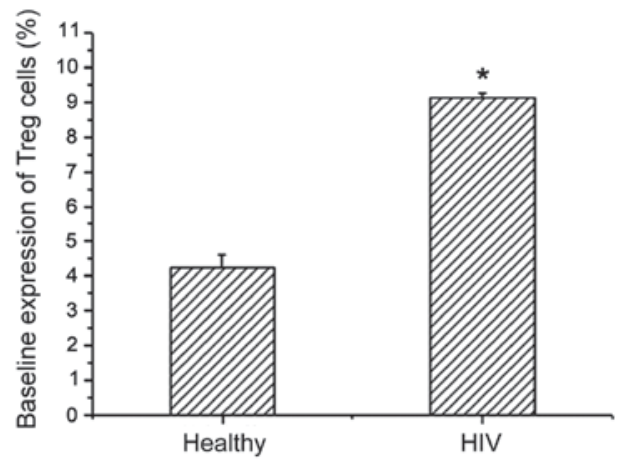

Figure 3. Baseline expressions of Treg cells in peripheral blood lymphocytes in the observation and control groups. "Statistically significant difference between groups at $\mathrm{P}<0.05$.

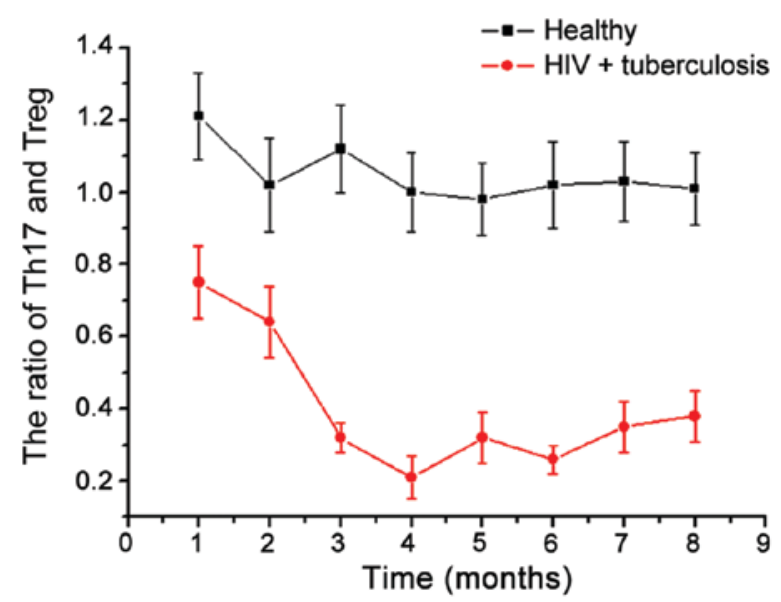

Figure 4. Changes of Th17/Treg ratio in peripheral blood lymphocytes in the observation and control groups.

Baseline expression of Th17 cells in peripheral blood lymphocytes. We next examined the expression levels of Th17 in healthy people and patients with AIDS complicated with TB infection by flow cytometry (Table I). Compared with healthy people, Th17 expression levels in AIDS patients with TB infection were significantly decreased, and there was a significant difference between them (Fig. 2). This suggests that the HIV virus can reduce the level of Th17 cells and thereby disrupt the immune system.

Expression of Treg in peripheral blood lymphocytes. Treg expression levels in healthy people and AIDS patients with TB infection were detected by flow cytometry (Table II). Compared with healthy people, the Treg level in AIDS patients with TB infection showed an increasing trend, and there was a significant difference between the two (Fig. 3). This shows that the immune system can enhance immunity by increasing the amount of Treg expression, thereby enhancing the ability to remove HIV.

Changes of Th17/Treg ratio in peripheral blood lymphocytes. We then examined the changes in Th17/Treg in healthy people and patients with HIV (Fig. 4). Compared with stable ratio of Th17/Treg in the healthy population, the Th17/Treg ratio in patients with AIDS complicated with TB infection had 


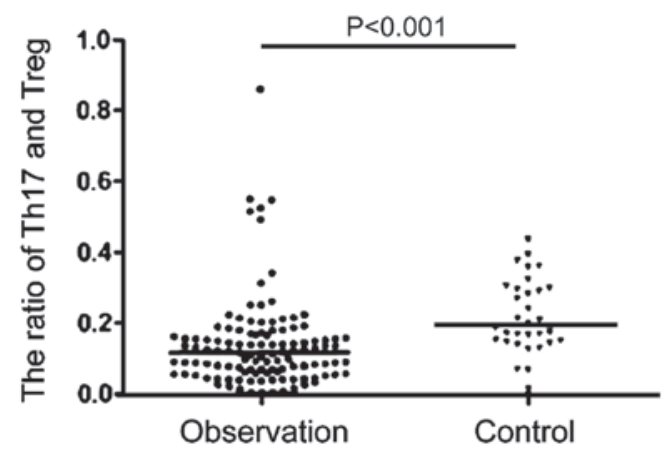

Figure 5. Correlation between Th17/Treg ratio and viral load in the observation and control groups.

greater variability. In the initial period of HIV infection, there was no significant change in the proportion of Th17/Treg, but over time, the Th17/Treg ratio showed a gradual downward trend. In the late stage, the Th17/Treg ratio showed a gradual upward trend; the Th17/Treg ratio strongly correlates with the stability of the collective immune system. With the Th17/Treg immune imbalance gradually increasing in the observation group, the difference in viral load was even more remarkable, which indicates that there is significant correlation between Th17/Treg immune imbalance and AIDS complicated with TB infection (Fig. 5).

Changes of IL-17, IL- 6 and IL-10 in peripheral blood lymphocytes. Finally, we detected the changes of IL-17, IL-6 and IL-10 by ELISA (Fig. 6). Compared with the levels of IL-17, IL-6 and IL-10 in healthy subjects $(3.02 \pm 0.48,3.13 \pm 0.76$, $2.89 \pm 0.83 \mathrm{pg} / \mathrm{ml})$, patients with AIDS complicated with TB infection showed significantly higher levels, and the differences were significant (Fig. 6). With the aggravation of the disease, IL expression decreased gradually, with the later stage showing significantly lower levels of IL-17, IL-6 and IL-10 than in the healthy population.

\section{Discussion}

TB infection is the main cause of death in AIDS patients and it also leads to many diseases following HIV infection (11). HIV can also promote the progression of TB in lung degeneration (12). Our study showed that co-infection of HIV with M. tuberculosis can accelerate the differentiation of immune cells. In this process, T cells induced by M. tuberculosis can activate virus replication to promote HIV transformation of non-infectious into infectious, and finally promote the transition to AIDS and the subsequent deterioration. In recent years, research has shown that HIV associated with TB infection decreases the number of $\mathrm{CD}^{+}{ }^{+} \mathrm{T}$ cells and leads to the lack of related functions (13). The number of $C D 4^{+} \mathrm{T}$ cells is often used as an indicator to measure the immune system function. CD4 ${ }^{+} \mathrm{T}$ cells can be divided into Th17 cells and Treg cells (14). The number of Th17 and Treg cells and the proportion of $\mathrm{CD}^{+} \mathrm{T}$ cells are related to the development of the disease. For instance, in patients with acute respiratory distress syndrome (15), the $\mathrm{CD} 4^{+} \mathrm{T}$ cells gradually decreased as the condition gradually deteriorated and the Th17/Treg ratio gradually decreased (16). Here, we found that the Th17/Treg ratio
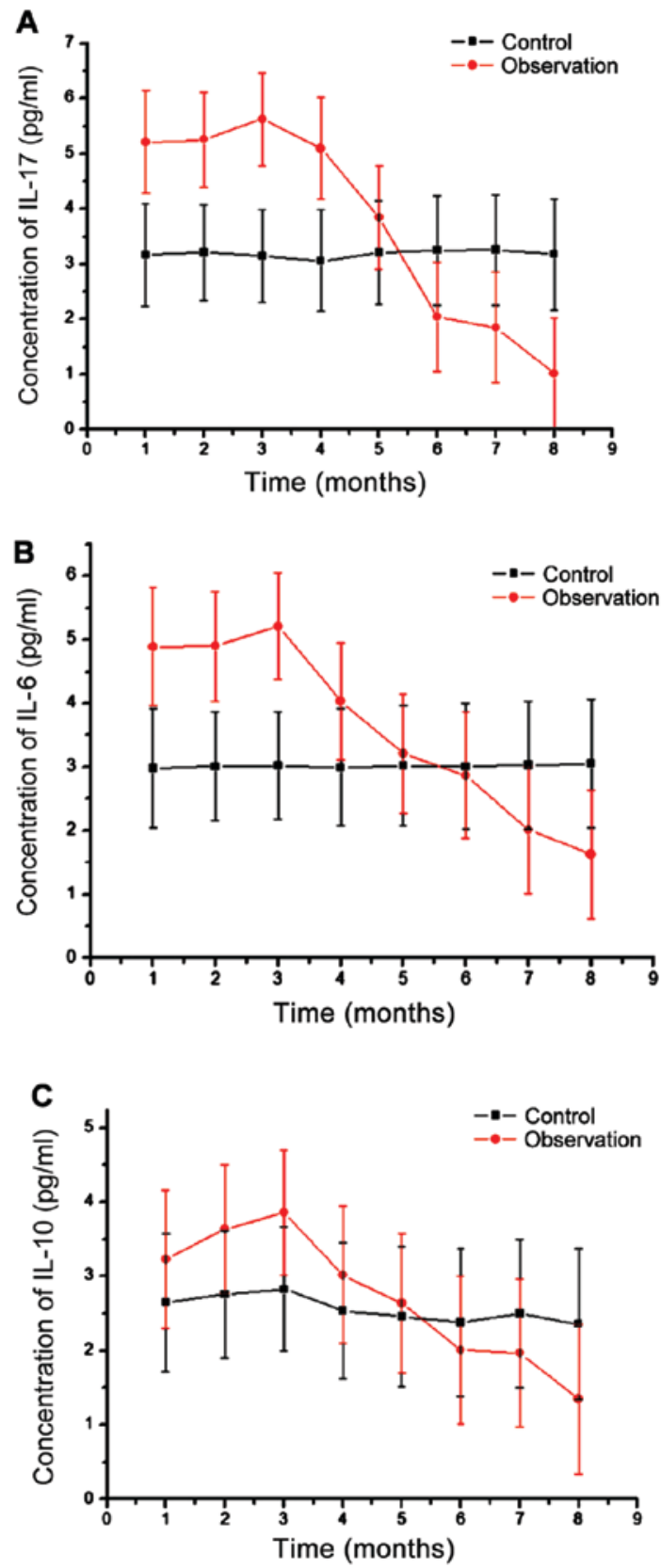

Figure 6. Changes of IL-17, IL-6 and IL-10 in peripheral blood lymphocytes in the observation and control groups. (A) Changes of IL-17 in peripheral blood lymphocytes over time. (B) Changes of IL-6 in peripheral blood lymphocytes over time. (C) Changes of IL-10 in peripheral blood lymphocytes over time. IL, interleukin.

also showed a tendency to decrease as AIDS/TB progressed. Study on Treg cells has shown that TGF- $\beta 1$ can promote the differentiation of $\mathrm{CD}^{+} \mathrm{T}$ cells into Treg cells, whereas Treg cells can block and inhibit viral replication, and thus play a therapeutic role in the treatment of disease (17). At the same time, Th17 cells are mainly involved in the inflammatory reaction (7), the abnormal increase of Th17 cells can induce autoimmune diseases $(18,19)$. Here, we measured Treg, Th17, and $\mathrm{CD}^{+}{ }^{+} \mathrm{T}$ cell changes and found that $\mathrm{CD} 4^{+} \mathrm{T}$ cells showed a gradual downward trend as AIDS with TB progressed. Also, the Treg/Th17 ratio was significantly reduced compared to the healthy group. This indicates that Treg/Th17 is imbalanced in patients with HIV combined with M. tuberculosis, and this 
immune imbalance leads to increased HIV replication. HIV mainly destroys the immune system and immune cells, so it eventually leads to a decrease in the number of major immune cells, such as $\mathrm{CD}^{+} \mathrm{T}$ cells, showing that the imbalance of Treg/Th17 can largely lead to aggravation of AIDS with TB infection.

\section{Competing interests}

The authors declare that they have no competing interests.

\section{References}

1. Singh A, Vajpayee M, Ali SA and Chauhan NK: Cellular interplay among Th17, Th1, and Treg cells in HIV-1 subtype 'C' infection. J Med Virol 86: 372-384, 2014

2. Heydenreich B, Bellinghausen I, König B, Becker WM, Grabbe S, Petersen A and Saloga J: Gram-positive bacteria on grass pollen exhibit adjuvant activity inducing inflammatory $\mathrm{T}$ cell responses. Clin Exp Allergy 42: 76-84, 2012.

3. Witte E, Witte K, Warszawska K, Sabat R and Wolk K: Interleukin-22: A cytokine produced by T, NK and NKT cell subsets, with importance in the innate immune defense and tissue protection. Cytokine Growth Factor Rev 21: 365-379, 2010.

4. Petrovas C, Yamamoto T, Gerner MY, Boswell KL, Wloka K, Smith EC, Ambrozak DC, Sandler NG, Timmer KJ, Sun X, et al: CD4 T follicular helper cell dynamics during SIV infection. J Clin Invest 122: 3281-3294, 2012.

5. Kim CJ, Nazli A, Rojas OL, Chege D, Alidina Z, Huibner S, Mujib S, Benko E, Kovacs C, Shin LYY, et al: A role for mucosal IL-22 production and Th22 cells in HIV-associated mucosal immunopathogenesis. Mucosal Immunol 5: 670-680, 2012.

6. de Paz B, Prado C, Alperi-López M, Ballina-García FJ, Rodriguez-Carrio J, López $\mathrm{P}$ and Suárez A: Effects of glucocorticoid treatment on $\mathrm{CD} 25^{-} \mathrm{FOXP}^{+}$population and cytokine-producing cells in rheumatoid arthritis. Rheumatology (Oxford) 51: 1198-1207, 2012.

7. Eyerich S, Wagener J, Wenzel V, Scarponi C, Pennino D, Albanesi C, Schaller M, Behrendt H, Ring J, Schmidt-Weber CB, et al: IL-22 and TNF- $\alpha$ represent a key cytokine combination for epidermal integrity during infection with Candida albicans. Eur J Immunol 41: 1894-1901, 2011.

8. Zeng M, Haase AT and Schacker TW: Lymphoid tissue structure and HIV-1 infection: Life or death for T cells. Trends Immunol 33: 306-314, 2012.
9. Zeng M, Smith AJ, Wietgrefe SW, Southern PJ, Schacker TW, Reilly CS, Estes JD, Burton GF, Silvestri G, Lifson JD, et al: Cumulative mechanisms of lymphoid tissue fibrosis and $\mathrm{T}$ cell depletion in HIV-1 and SIV infections. J Clin Invest 121: 998-1008, 2011.

10. Chege D, Sheth PM, Kain T, Kim CJ, Kovacs C, Loutfy M, Halpenny R, Kandel G, Chun TW, Ostrowski M, et al; Toronto Mucosal Immunology Group: Sigmoid Th17 populations, the HIV latent reservoir, and microbial translocation in men on long-term antiretroviral therapy. AIDS 25: 741-749, 2011.

11. Mai J, Wang H and Yang XF: Th 17 cells interplay with Foxp3 ${ }^{+}$ Tregs in regulation of inflammation and autoimmunity. Front Biosci (Landmark Ed) 15: 986-1006, 2010.

12. Caccamo N, Pietra G, Sullivan LC, Brooks AG, Prezzemolo T, La Manna MP, Di Liberto D, Joosten SA, van Meijgaarden KE, Di Carlo P, et al: Human CD8 T lymphocytes recognize Mycobacterium tuberculosis antigens presented by HLA-E during active tuberculosis and express type 2 cytokines. Eur J Immunol 45: 1069-1081, 2015.

13. Tsai HC, Velichko S, Hung LY and Wu R: IL-17A and Th17 cells in lung inflammation: An update on the role of Th17 cell differentiation and IL-17R signaling in host defense against infection. Clin Dev Immunol 2013: 267971, 2013.

14. Hu Y, Zhang J, Li X, Yang Y, Zhang Y, Ma J and Xi L: Penicillium marneffei infection: An emerging disease in mainland China. Mycopathologia 175: 57-67, 2013.

15. Basile G, Paffumi I, D'Angelo AG, Figliomeni P, Cucinotta MD, Pace E, Ferraro M, Saitta S, Lasco A and Gangemi S: Healthy centenarians show high levels of circulating interleukin-22 (IL-22). Arch Gerontol Geriatr 54: 459-461, 2012.

16. Engelhardt KR and Grimbacher B: Mendelian traits causing susceptibility to mucocutaneous fungal infections in human subjects. J Allergy Clin Immunol 129: 294-307, 2012.

17. Presicce P, Shaw JM, Miller CJ, Shacklett BL and Chougnet CA: Myeloid dendritic cells isolated from tissues of SIV-infected Rhesus macaques promote the induction of regulatory $\mathrm{T}$ cells. AIDS 26: 263-273, 2012.

18. Salgado M, Rallón NI, Rodés B, López M, Soriano V and Benito JM: Long-term non-progressors display a greater number of Th17 cells than HIV-infected typical progressors. Clin Immunol 139: 110-114, 2011.

19. Matthews K, Wilkinson KA, Kalsdorf B, Roberts T, Diacon A, Walzl G, Wolske J, Ntsekhe M, Syed F, Russell J, et al: Predominance of interleukin-22 over interleukin-17 at the site of disease in human tuberculosis. Tuberculosis (Edinb) 91: 587-593, 2011.

This work is licensed under a Creative Commons Attribution-NonCommercial-NoDerivatives 4.0 International (CC BY-NC-ND 4.0) License. 